\title{
Pengembangan CD Interaktif Macromedia Flash Sistem Reproduksi Manusia untuk Meningkatkan Pemahaman Konsep dan Berpikir Kreatif
}

\author{
Noor Elies Saptaningrum*) \\ ${ }^{*}$ MTs Muhamadiyah Bucu Bangsri Jepara \\ eliessaptaningrum@gmail.com
}

\begin{abstract}
ABSTRAK
Tujuan penilitian ini adalah untuk menghasilkan CD interaktif berbasis macromedia flash sebagai media pembelajaran di MA Matholi'ul Huda Jepara khususnya pada mata pelajaran Biologi istem eproduksi manusia dan menganalisis pengaruh pengembangan $\mathrm{CD}$ interaktif berbasis macromedia flash sistem reproduksi manusia terhadap meningkatkan pemahaman konsep dan berpikir kreatif siswa. Penelitian menggunakan metode penelitian R \& D dengan langkah sebagai berikut; pengumpulan data,pembuatan produk awal, penilaian pakar, revisi 1, uji coba lapangan, revisi 2, penilaian pakar, (produksi masal). Hasil penelitian dari pakar menunjukan skor $81,25 \%$ dengan keterangan layak untuk digunakan di MA Matholi'ul Huda Jepara dan skor $93 \%$ dari angket ketertarikan siswa. Hasil penelitian di kelas XI IPA 1 menunjukkan analisis berfikir kreatif mendapat $\mathrm{t}$ hitung $-53,548$, analisis pemahaman konsep siswa mendapat $\mathrm{t}$ hitung -75,836, menunjukan bahwa berfikir kreatif dan pemahaman konsep siswa meningkat, maka hipotesis diterima, artinya terdapat peningkatan berfikir kreatif dan pemahaman kosep siswa menggunakan media pembelajaran CD interaktif.
\end{abstract}

Kata Kunci : CD interaktif, pemahaman konsep, berpikir kreatif

\begin{abstract}
The purpose of this research is to produce an interactive CD based on macromedia flash as a learning medium in MA Matholi'ul Huda Jepara, especially on Biology Subject of human epistem system and development of interactive $C D$ development based on macromedia flash system. Research using $R$ $\& D$ research method with the following steps; flow data, initial product creation, expert change, revision 1, field trials, revision 2, re-expert, (mass production). The results of the expert's research showed a score of $81.25 \%$ with descriptive descriptions for MA Matholi'ul Huda Jepara and 93\% score from questionnaire of student interest. The results of reseach in class XI IPA 1 analysis of creative thinking gets $t$ arithmetic - 53,548, analysis of concept comprehension of student get t arithmetic-75,836, show that creative thinking and comprehension of student
\end{abstract}


concept increase, hence hypothesis accepted, creative thinking and creative thinking by using interactive learning media $C D$.

Keywords: interactive $C D$, concept comprehension, creative thinking

\section{PENDAHULUAN}

Manfaat media teknologi dalam pendidikan yaitu untuk meningkatkan produktivitas pendidikan, memberikan kemungkinan kegiatan pengajaran bersifat individual, memberikan dasar yang lebih dinamis terhadap pendidikan, pengajaran yang lebih mantap, memungkinkan belajar secara seketika dan penyajian pendidikan secara luas (Sudarman, 1995 ). Salah satu media yang dirasa perlu untuk dikembangkan dalam dunia pendidikan adalah CD interaktif karena dapat digunakan terutama pada proses pembelajaran mandiri dan terbuka dan dapat dijalankan dengan komputer, yang menggunakan CD player. Berbagai fasilitas baik fasilitas suara (audio) dan fasilitas gambar (video) dan berbagai fasilitas khusus lainnya (Rachmanto, 2005).

Penggunaan CD interaktif berbasis macromedia flash ini dalam pembelajaran biologi di SMA sangat dibutuhkan, banyak materi yang bagi sebagian siswa mungkin mengalami kesulitan untuk memahami materi tersebut. Berdasarkan penjelasan dari seorang guru biologi SMA tentang materi biologi semester I, kesulitan yang dihadapi siswa ketika mempelajari materi yang ada dibuku adalah gambar yang ada biasa dan tidak bewarna seperti proses-proses fisiologi misalnya spermatogenesis, oogenesis, siklus menstruasi. Sehingga siswa kesulitan untuk mempelajari gambar-gambar tersebut, oleh sebab itu diperlukan gambar-gambar animasi dalam bentuk flash agar siswa lebih mudah untuk memahami secara lebih detail bagian- bagian dari gambar.

Pemilihan media yang tepat dan menarik dapat juga membantu guru untuk menyampaikan materi biologi dengan lebih baik. Salah satunya menggunakan animasi dengan komputer. Untuk itu perlu dibuat sebuah CD Interaktif berbasis macromedia flash yang dapat menjelaskan tentang materi biologi pada kompetensi dasar sistem reproduksi pada manusia. Selain itu banyak kelebihan dari CD interaktif berbasis macromedia flash dibandingkan CD interaktif lainnya yaitu CD interaktif berbasis macromedia flash efektif digunakan dalam pembelajaran karena sesuai dengan standar kompetensi dan kompetensi dasarnya. 
Adapun tujuan penelitian ini meliputi 1) Menghasilkan CD interaktif berbasis macromedia flash sistem reproduksi pada manusia sesuai dengan standar kompetensi dan kompetensi dasar pembelajaran di MA Matholi'ul huda Jepara. 2) menghasilkan CD interaktif berbasis macromedia flash sistem reproduksi pada manusia efektif dapat meningkatkan pemahaman konsep dan berpikir kreatif siswa kelas XI IPA di MA Matholi'ul Huda Jepara.

\section{METODE PENELITIAN}

Penelitian ini dilaksanakan di MA Matholi'ul Huda Jepara. Waktu penelitiannya yaitu pada bulan Mei. Subjek penelitian ini adalah ahli macromedia flash, guru, dan semua siswa kelas XI IPA MA Matholi'ul Huda Jepara. Penelitian mempunyai dua variabel yakni variabel bebas dan variabel terikat. Variabel bebas berupa $\mathrm{CD}$ interaktif sistem reproduksi manusia berbasis macromedia flash. Variabel terikat berupa berfikir kreatif dan pemahaman konsep

Jenis penelitian ini dengan menggunakan pendekatan penelitian dan pengembangan (Research And Development). Metode penelitian Research And Development (R\&D) digunakan untuk menghasilkan produk dan menguji keefektifannya. Menurut Borg and Gall menyatakan bahwa penelitian dan pengembangan (Research and Development /R\&D), merupakan metode penelitian yang di gunakan untuk mengembangkan dan memvalidasi suatu pruduk-produk yang digunakan dalam pendidikan dan pembelajaran (Sugiyono, 2009).

\section{HASIL DAN PEMBAHASAN}

Hasil Penelitian

Hasil penelitian dapat diketahui bahwa terjadi peningkatan terhadap pemahaman konsep siswa pada pembelajaran biologi setelah menggunakan $C D$ intraktif berbasis macromedia flash di kelas XI IPA 1, XI IPA 2, dan XI IPA 3. Hasil analisis pemahaman konsep kelas XI IPA 1 tersaji pada Tabel 1 
Tabel 1. Hasil Analisis Pemahaman Konsep Siswa Kelas XI IPA 1

Paired Samples Test

\begin{tabular}{cccccccc}
\hline & \multicolumn{4}{c}{ Paired Differences } & & & Sig. \\
\cline { 2 - 6 } & Mean & $\begin{array}{c}\text { Std. } \\
\text { Deviation }\end{array}$ & $\begin{array}{c}\text { Std. Error } \\
\text { Mean }\end{array}$ & t & df & $\begin{array}{c}\text { Sig. } \\
\text { (2-tailed) }\end{array}$ \\
\hline 1 & 2 & 4 & 4 & 6 & 7 & 8 \\
\hline $\begin{array}{c}\text { Pair } \\
1\end{array}$ & $\begin{array}{c}\text { PKonsep Pre }- \\
\text { PkonsepPost }\end{array}$ & -45.34884 & 4.80517 & .73278 & -61.886 & 42 & .000 \\
\hline
\end{tabular}

Berdasarkan Tabel 1 dapat diketahui bahwa t hitung - 61,886, menunjukan bahwa pemahaman konsep siswa pada pembelajaran sebelum menggunakan media CD interaktif berbasis macromedia flash lebih rendah dari pembelajaran setelah menggunakan CD interaktif berbasis macromedia flash. Sedangkan harga signifikasi $(\mathrm{p})$, nilai $\mathrm{p}=0,000$, dimana nilai tersebut $(\mathrm{p}<0,05)$, maka terdapat beda rata - rata nilai antara pembelajaran sebelum menggunakan media CD interaktif berbasis macromedia flash dan setelah menggunakan CD interaktif berbasis macromedia flash, sehingga penggunaan CD interaktif berbasis macromedia flash efektif untuk meningkatkan pemahaman konsep siswa di kelas XI IPA 1. Hasil analisis pemahaman konsep siswa kelas XI IPA 2 tersaji pada Tabel 2

Tabel 2 Hasil Analisis Pemahaman Konsep Kelas XI IPA 2

Paired Samples Test

\begin{tabular}{|c|c|c|c|c|c|c|c|}
\hline & & \multicolumn{3}{|c|}{ Paired Differences } & & \multirow[b]{2}{*}{ df } & \multirow{2}{*}{$\begin{array}{c}\text { Sig. } \\
\text { (2-tailed) }\end{array}$} \\
\hline & & Mean & $\begin{array}{c}\text { Std. } \\
\text { Deviation }\end{array}$ & $\begin{array}{l}\text { Std. Error } \\
\text { Mean }\end{array}$ & & & \\
\hline 1 & 2 & 3 & 4 & 5 & 6 & 7 & 8 \\
\hline $\begin{array}{c}\text { Pair } \\
1\end{array}$ & $\begin{array}{l}\text { PKonsep Pre - } \\
\text { Pkonsep Post }\end{array}$ & -39.26190 & 4.10270 & .63306 & -62.019 & 41 & .000 \\
\hline
\end{tabular}

Berdasarkan Tabel 2 dapat diketahui bahwa t hitung - 62,019, menunjukan bahwa pemahaman konsep siswa pada pembelajaran sebelum menggunakan media CD interaktif berbasis macromedia flash lebih rendah dari pembelajaran setelah menggunakan CD interaktif berbasis macromedia flash. Sedangkan harga signifikasi $(\mathrm{p})$, nilai $\mathrm{p}=0,000$, dimana nilai tersebut $(\mathrm{p}<0,05)$, maka terdapat beda rata - rata nilai antara pembelajaran sebelum menggunakan media CD interaktif 
berbasis macromedia flash dan setelah menggunakan $\mathrm{CD}$ interaktif berbasis macromedia flash, sehingga penggunaan CD interaktif berbasis macromedia flash efektif untuk meningkatkan pemahaman konsep siswa di kelas XI IPA 2. Hasil analisis pemahaman konsep siswa kelas XI IPA 3 tersaji pada Tabel 4.6

Tabel 3 Hasil Analisis Pemahaman Konsep Kelas XI IPA 3

\begin{tabular}{|c|c|c|c|c|c|c|c|}
\hline & Aspek & Mean & $\begin{array}{c}\text { Std. } \\
\text { Deviatio } \\
\text { n }\end{array}$ & $\begin{array}{l}\text { Std. } \\
\text { Error } \\
\text { Mean }\end{array}$ & & & \\
\hline 1 & 2 & 3 & 4 & 5 & 6 & 7 & 8 \\
\hline $\begin{array}{l}\text { Pai } \\
\text { r } 1\end{array}$ & $\begin{array}{c}\text { PKonsep Pre } \\
\text { - Pkonsep } \\
\text { Post }\end{array}$ & -42.85294 & 3.29492 & .56507 & $\begin{array}{c}- \\
75.83 \\
6\end{array}$ & $\begin{array}{l}3 \\
3\end{array}$ & .000 \\
\hline
\end{tabular}

Berdasarkan Tabel 3 dapat diketahui bahwa t hitung - 75,836, menunjukan bahwa pemahaman konsep siswa pada pembelajaran sebelum menggunakan media CD interaktif berbasis macromedia flash lebih rendah dari pembelajaran setelah menggunakan CD interaktif berbasis macromedia flash. Sedangkan harga signifikasi $(\mathrm{p})$, nilai $\mathrm{p}=0,000$, dimana nilai tersebut $(\mathrm{p}<0,05)$, maka terdapat beda rata - rata nilai antara pembelajaran sebelum menggunakan media CD interaktif berbasis macromedia flash dan setelah menggunakan $\mathrm{CD}$ interaktif berbasis macromedia flash, sehingga penggunaan CD interaktif berbasis macromedia flash efektif untuk meningkatkan pemahaman konsep siswa di kelas XI IPA 3.

Berdasarkan dari pertimbangan para pakar, maka dilakukan revisi terhadap produk awal CD interaktif berbasis macromedia flash, yaitu penambahan terhadap materi yang dianggap masih kurang, serta penggantian gambar - gambar materi yang dinilai kurang jelas bila digunakan sebagai media pembelajaran. Contoh gambar materi pada CD interaktif berbasis macromedia flash setelah direvisi adalah sebagai berikut: 


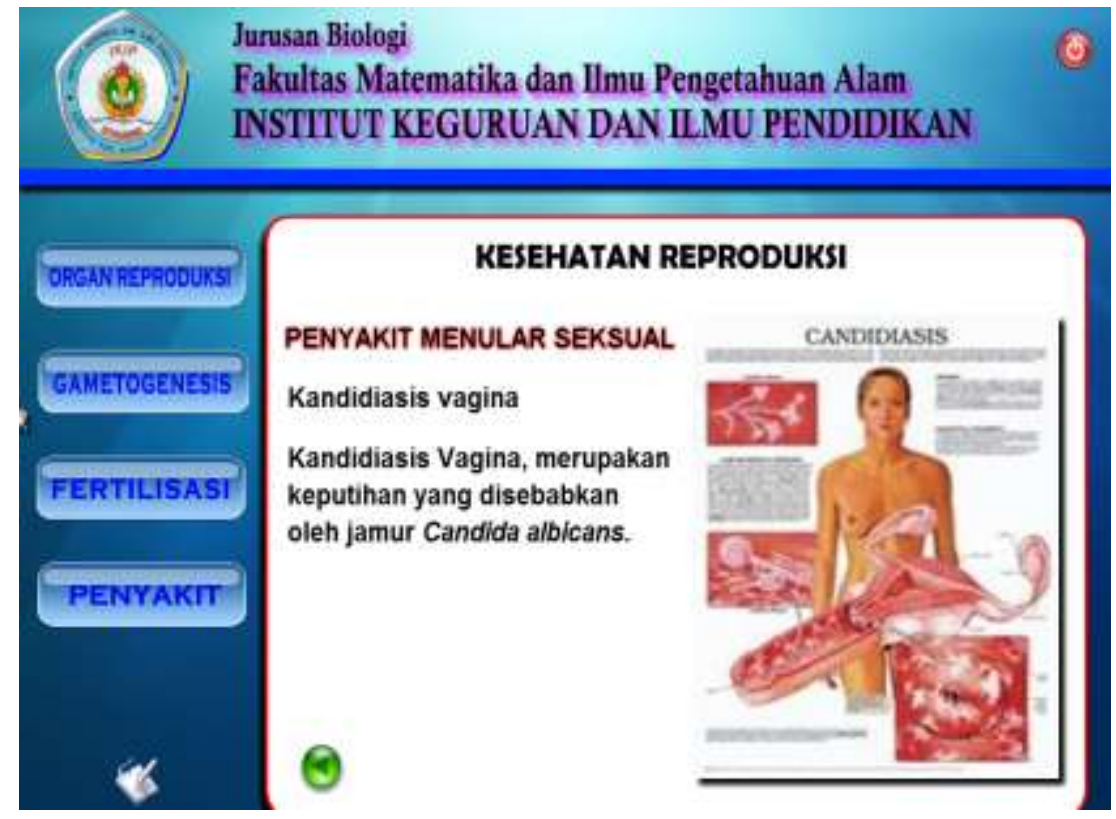

Gambar 4.3 Materi yang masih salah

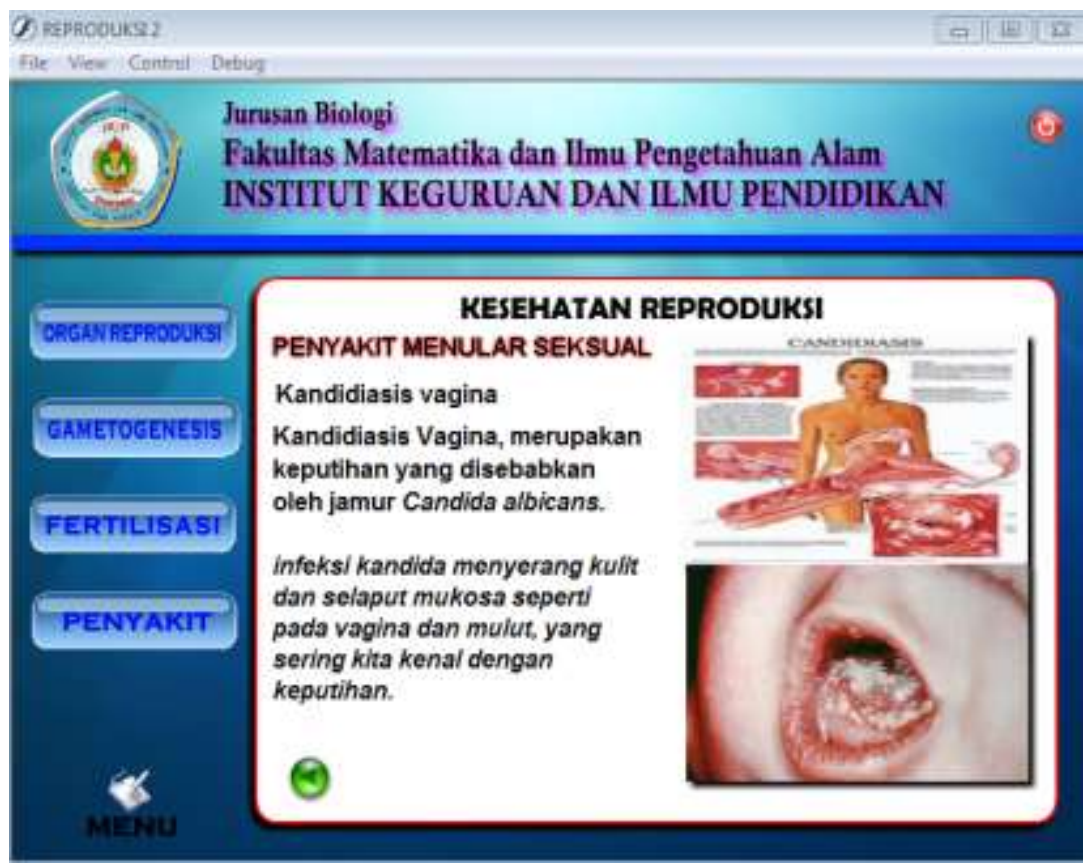

Gambar 4.4 Materi setelah direvisi

Hasil analisis dapat diketahui bahwa berpikir kreatif siswa pada pembelajaran biologi di kelas XI IPA 1, XI IPA 2, dan XI IPA 3 mengalami 
peningkatan setelah mengunakan CD interaktif berbasis macromedia flash. Hasil analisis berpikir kreatif siswa kelas XI IPA 1 tersaji pada Tabel 4.

Tabel 4. Hasil Analisis Berpikir Kreatif Kelas XI IPA 1

\begin{tabular}{|c|c|c|c|c|c|c|c|}
\hline & \multirow[b]{2}{*}{ Aspek } & \multicolumn{3}{|c|}{ Paired Differences } & \multirow[b]{2}{*}{$\mathrm{t}$} & \multirow[b]{2}{*}{ Df } & \multirow[b]{2}{*}{$\begin{array}{c}\text { Sig. } \\
\text { (2-tailed) }\end{array}$} \\
\hline & & Mean & $\begin{array}{c}\text { Std. } \\
\text { Deviation }\end{array}$ & $\begin{array}{l}\text { Std. Error } \\
\text { Mean }\end{array}$ & & & \\
\hline 1 & 2 & 3 & 4 & 5 & 6 & 7 & 8 \\
\hline $\begin{array}{c}\text { Pair } \\
1\end{array}$ & $\begin{array}{c}\text { Brpkr Kreatif Pre - } \\
\text { Brpkr Kreatif Post }\end{array}$ & -65.34884 & 8.00263 & 1.22039 & -53.548 & 42 & .000 \\
\hline
\end{tabular}

Berdasarkan Tabel 4.7 dapat diketahui bahwa $t$ hitung - 53,548, menunjukan bahwa berpikir kreatif siswa pada pembelajaran sebelum menggunakan media CD interaktif berbasis macromedia flash lebih rendah dari pembelajaran setelah menggunakan $\mathrm{CD}$ interaktif berbasis macromedia flash. Sedangkan harga signifikasi $(\mathrm{p})$, dimana nilai $\mathrm{p}=0,000$, dimana nilai tersebut $(\mathrm{P}<$ 0,05), maka terdapat beda rata - rata nilai antara pembelajaran sebelum menggunakan media $\mathrm{CD}$ interaktif berbasis macromedia flash dan setelah menggunakan $\mathrm{CD}$ interaktif berbasis macromedia flash, sehingga penggunaan CD interaktif berbasis macromedia flash efektif untuk meningkatkan berpikir kreatif siswa di kelas XI IPA 1. Hasil analisis berpikir kreatif siswa kelas XI IPA 2 tersaji pada Tabel 5

Tabel 5 Hasil Analisis Berpikir Kreatif Kelas XI IPA 2

\begin{tabular}{|c|c|c|c|c|c|c|}
\hline & \multicolumn{3}{|c|}{ Paired Differences } & \multirow[b]{2}{*}{$\mathrm{t}$} & \multirow[b]{2}{*}{ df } & \multirow[b]{2}{*}{$\begin{array}{c}\text { Sig. (2 } \\
- \\
\text { tailed) }\end{array}$} \\
\hline Aspek & Mean & $\begin{array}{c}\text { Std. } \\
\text { Deviatio } \\
\mathrm{n}\end{array}$ & $\begin{array}{c}\text { Std. } \\
\text { Error } \\
\text { Mean }\end{array}$ & & & \\
\hline Brpkr Kreatif & - & 7.74120 & 1.19449 & - & 4 & .000 \\
\hline Pre-Brpkr & 55.30952 & & & 46.30 & 1 & \\
\hline Kreatif Post & & & & 4 & & \\
\hline
\end{tabular}

Berdasarkan Tabel 5 dapat diketahui bahwa t hitung - 46,304, menunjukan bahwa berpikir kreatif siswa pada pembelajaran sebelum menggunakan media CD interaktif berbasis macromedia flash lebih rendah dari pembelajaran setelah menggunakan CD interaktif berbasis macromedia flash. Sedangkan harga signifikasi $(p)$, nilai $p=0,000$, dimana nilai tersebut $(p<0,05)$, maka terdapat beda rata - rata nilai antara pembelajaran sebelum menggunakan media CD interaktif berbasis macromedia flash dan setelah menggunakan $\mathrm{CD}$ interaktif berbasis 
macromedia flash, sehingga penggunaan CD interaktif berbasis macromedia flash efektif untuk meningkatkan berpikir kreatif siswa di kelas XI IPA 2. Hasil analisis berpikir kreatif siswa kelas XI IPA 3 tersaji pada Tabel 6

Tabel 6 Hasil Analisis Berpikir Kreatif Kelas XI IPA 3

\begin{tabular}{ccccccc}
\hline & \multicolumn{3}{c}{ Paired Differences } & & Aspek \\
\cline { 2 - 4 } & Mean & $\begin{array}{c}\text { Std. } \\
\text { Deviation }\end{array}$ & $\begin{array}{c}\text { Std. Error } \\
\text { Mean }\end{array}$ & t & df $\begin{array}{c}\text { Sig. (2- } \\
\text { tailed) }\end{array}$ \\
\hline $\begin{array}{l}\text { Brpkr Kreatif Pre }- \\
\text { Brpkr Kreatif Post }\end{array}$ & -52.97059 & 6.12241 & 1.04999 & -50.449 & 33 & .000 \\
\hline
\end{tabular}

Berdasarkan Tabel 6 dapat diketahui bahwa t hitung - 50,449, menunjukan bahwa berpikir kreatif siswa pada pembelajaran sebelum menggunakan media CD interaktif berbasis macromedia flash lebih rendah dari pembelajaran setelah menggunakan CD interaktif berbasis macromedia flash. Sedangkan harga signifikasi $(p)$, nilai $p=0,000$, dimana nilai tersebut $(p<0,05)$, maka terdapat beda rata - rata nilai antara pembelajaran sebelum menggunakan media CD interaktif berbasis macromedia flash dan setelah menggunakan $\mathrm{CD}$ interaktif berbasis macromedia flash, sehingga penggunaan CD interaktif berbasis macromedia flash efektif untuk meningkatkan berpikir kreatif siswa di kelas XI IPA 3.

Hasil analisis tanggapan siswa pada uji lapangan CD interaktif berbasis macromedia flash di kelas XI IPA 1, XI IPA 2, XI IPA3 disajikan pada Tabel 4.10.

Tabel 7 Hasil Analisis Tanggapan Siswa

\begin{tabular}{cccccccc}
\hline No & $\begin{array}{c}\text { Kode } \\
\text { Item }\end{array}$ & \multicolumn{2}{c}{ Skor diperoleh } & \multicolumn{3}{c}{ Kriteria } \\
\cline { 2 - 7 } & IA 1 & IA 2 & IA 3 & IA 1 & IA 2 & IA 3 \\
\hline 1 & A & 98.8 & 94.8 & 92.6 & $\begin{array}{c}\text { Sangat } \\
\text { Tertarik }\end{array}$ & $\begin{array}{c}\text { Sangat } \\
\text { Tertarik }\end{array}$ & $\begin{array}{c}\text { Sangat } \\
\text { Tertarik }\end{array}$ \\
\hline 2 & B & 91.7 & 92.4 & 93.4 & $\begin{array}{c}\text { Sangat } \\
\text { Tertarik }\end{array}$ & $\begin{array}{c}\text { Sangat } \\
\text { Tertarik }\end{array}$ & $\begin{array}{c}\text { Sangat } \\
\text { Tertarik }\end{array}$ \\
\hline 3 & C & 89.9 & 88.4 & 92.6 & $\begin{array}{c}\text { Sangat } \\
\text { Tertarik }\end{array}$ & $\begin{array}{c}\text { Sangat } \\
\text { Tertarik }\end{array}$ & $\begin{array}{c}\text { Sangat } \\
\text { Tertarik }\end{array}$ \\
\hline 4 & D & 92.3 & 90.1 & 91.9 & $\begin{array}{c}\text { Sangat } \\
\text { Tertarik }\end{array}$ & $\begin{array}{c}\text { Sangat } \\
\text { Tertarik }\end{array}$ & $\begin{array}{c}\text { Sangat } \\
\text { Tertarik }\end{array}$ \\
\hline 5 & E & 92.3 & 94.2 & 90.4 & $\begin{array}{c}\text { Sangat } \\
\text { Tertarik }\end{array}$ & $\begin{array}{c}\text { Sangat } \\
\text { Tertarik }\end{array}$ & $\begin{array}{c}\text { Sangat } \\
\text { Tertarik }\end{array}$ \\
\hline 6 & F & 88.7 & 93.0 & 87.5 & Sangat & Sangat & Sangat \\
\hline
\end{tabular}




\begin{tabular}{|c|c|c|c|c|c|c|c|}
\hline & & & & & Tertarik & Tertarik & Tertarik \\
\hline 7 & G & 94.6 & 91.9 & 86.8 & $\begin{array}{c}\text { Sangat } \\
\text { Tertarik }\end{array}$ & $\begin{array}{c}\text { Sangat } \\
\text { Tertarik }\end{array}$ & $\begin{array}{c}\text { Sangat } \\
\text { Tertarik }\end{array}$ \\
\hline 8 & $\mathrm{H}$ & 93.5 & 92.4 & 91.9 & $\begin{array}{c}\text { Sangat } \\
\text { Tertarik }\end{array}$ & $\begin{array}{c}\text { Sangat } \\
\text { Tertarik }\end{array}$ & $\begin{array}{c}\text { Sangat } \\
\text { Tertarik }\end{array}$ \\
\hline 9 & I & 88.7 & 93.0 & 84.6 & $\begin{array}{c}\text { Sangat } \\
\text { Tertarik }\end{array}$ & $\begin{array}{c}\text { Sangat } \\
\text { Tertarik }\end{array}$ & $\begin{array}{c}\text { Sangat } \\
\text { Tertarik }\end{array}$ \\
\hline 10 & $\mathrm{~J}$ & 89.9 & 100 & 90.4 & $\begin{array}{c}\text { Sangat } \\
\text { Tertarik }\end{array}$ & $\begin{array}{c}\text { Sangat } \\
\text { Tertarik }\end{array}$ & $\begin{array}{c}\text { Sangat } \\
\text { Tertarik }\end{array}$ \\
\hline Per & $\begin{array}{l}\text { tase } \\
\text { is }\end{array}$ & 93.0 & 92.0 & 90.2 & $\begin{array}{c}\text { Sangat } \\
\text { Tertarik }\end{array}$ & $\begin{array}{c}\text { Sangat } \\
\text { Tertarik }\end{array}$ & $\begin{array}{c}\text { Sangat } \\
\text { Tertarik }\end{array}$ \\
\hline
\end{tabular}

Dari Tabel 7 diketahui bahwa terdapat tanggapan yang positif dari siswa kelas XI IPA 1, XI IPA 2, dan XI IPA 3 terhadap CD interaktif berbasis macromedia flash. Dari setiap aspek tanggapan yang diberikan, siswa menyatakan sangat tertarik dan setuju dengan penggunaan $\mathrm{CD}$ interaktif berbasis macromedia flash sebagai media pembelajaran.

1. Hasil Tanggapan Guru Terhadap Pengembangan CD interaktif berbasis macromedia flash.

Hasil tanggapan guru terhadap CD interaktif berbasis macromedia flash disajikan dalam Tabel 8.

Tabel 8 Hasil analisis tanggapan guru

\begin{tabular}{ccccc}
\hline No & Guru & $\begin{array}{c}\text { Jumlah } \\
\text { Skor }\end{array}$ & $\begin{array}{c}\text { Persentase } \\
\text { Yang Dicapai }\end{array}$ & Ket \\
\hline 1 & Guru Biologi & 74 & 92,507 & Sangat Efektif \\
\hline
\end{tabular}

Berdasarkan Tabel 8 dapat diketahui bahwa terdapat tanggapan yang positif dari guru biologi terhadap CD interaktif berbasis macromedia flash. Dari setiap aspek tanggapan yang diberikan, guru biologi menyatakan bahwa penggunaan CD interaktif berbasis macromedia flash sangat efektif.

Dari hasil analisis dapat diketahui bahwa CD interaktif berbasis macromedia flash yang dikembangkan oleh peneliti telah layak untuk digunakan sebagai media pembelajaran. Kelayakan tersebut terbukti dari Tabel 1 dimana hasil analisis penilaian pakar yang memperoleh persentase $81,25 \%$ pada bidang media dan $80 \%$ pada bidang materi. 
Sudarman, 1995 menyatakan bahwa manfaat media tehnologi pendidikan mampu meningkatkan produktifitas pendidikan, memberikan kemungkinan kegiatan pengajaran bersifat individual, memberikan dasar yang lebih dinamis terhadap pendidikan, pengajaran yang lebih mantap, memungkinkan peningkatan aktivitas siswa dan penyajian pendidikan secara luas. Hal itulah yang menjadikan dasar pengembangan $\mathrm{CD}$ interaktif berbasis macromedia flash berbasis macromedia flash.

CD interaktif berbasis macromedia flash berbasis macromedia flash yang dikembangkan telah mampu meningkatkan berpikir kreatif dan pemahaman konsep siswa kelas XI IPA di MA Matholi'ul Huda. Ini dikarenakan dalam CD interaktif berbasis macromedia flash menggunakan gambar - gambar materi yang jelas, video dan audio yang menarik dan terdapat tombol - tobol yang dapat diakses oleh siswa untuk memperoleh materi - materi dalam pembelajaran. Di sini siswa tidak hanya dapat membaca materi yang disajikan, namun juga dapat mendengarkan narasi materi yang tersaji. Selain itu juga terdapat soal - soal interaktif yang dapat diakses siswa secara langsung. Dengan media yang menarik dan mengasikkan ini maka siswa akan terdorong untuk berinteraksi secara langsung dengan media, teman, maupun dengan guru.

Dengan adanya interaksi-interaksi yang dilakukan oleh siswa baik dengan media, teman, maupun dengan guru, maka siswa akan lebih mudah dalam membangun pemahaman terhadap sebuah materi yang disampaikan. Dan selanjutnya akan berdampak terhadap kemampuan siswa untuk mengkontruksi ide- ide baru. Dengan begitu pemahaman konsep dan berfikir kreatif siswa dapat dikatakan meningkat. Ini sesuai dengan pendapat yang menyatakan bahwa kemampuan berpikir kreatif adalah kemampuan untuk menghasilkan ide atau cara baru dalam menghasilkan suatu produk. Pada umumnya, berpikir kreatif dipicu oleh masalah-masalah yang menantang, Martin (2009).

Peningkatan berpikir kreatif dan pemahaman konsep siswa terbukti dari hasil analisis berpikir kreatif siswa secara klasikal yang diperoleh persentase $96 \%$ pada kelas XI IPA 1, $93 \%$ pada kelas XI IPA 2, dan $92 \%$ pada kelas XI IPA 3. Dan hasil analisis pemahaman konsep siswa secara klasikal diperoleh persentase $97 \%$ pada kelas XI IPA 1, $94 \%$ pada kelas XI IPA 2, $98 \%$ pada kelas XI IPA 3. 
Maka CD interaktif berbasis macromedia flash berbasis macromedia flash yang dikembangkan sangat efektif untuk meningkatkan berpikir kreatif dan pemahaman konsep siswa kelas XI IPA di MA Matholi'ul Huda. Hal ini sesuai dengan Tabel 4.1 yaitu penilaian pakar yang memperoleh persentase lebih dari 80 $\%$, dan perolehan persentase secara klasikal pada minat belajar dan aktifitas siswa yang mencapai lebih dari $80 \%$.

\section{SIMPULAN}

Simpulan pada penelitian ini bahwa pertama penggunaan CD interaktif berbasis macromedia flash yang sesuai SK dan KD pada silabus kelas X di MA Matholi'ul Huda. Kedua, CD interaktif berbasis macromedia flash sistem reproduksi manusia mampu meningkatkan pemahaman konsep dan berpikir kreatif. Ketiga, Peningkatan berpikir kreatif dan pemahaman konsep siswa terbukti dari hasil analisis berpikir kreatif siswa secara klasikal yang diperoleh persentase $96 \%$ pada kelas XI IPA 1, $93 \%$ pada kelas XI IPA 2, dan $92 \%$ pada kelas XI IPA 3. Dan hasil analisis pemahaman konsep siswa secara klasikal diperoleh persentase $97 \%$ pada kelas XI IPA 1, $94 \%$ pada kelas XI IPA 2, $98 \%$ pada kelas XI IPA 3.

\section{DAFTAR PUSTAKA}

Amin, M. (2009). Biologi SMA/MA XI . Jakarta : Bumi Aksara.

Arikunto, S. (1999). Dasar-Dasar Evaluasi Pendidikan. Jakarta : Bumi Aksara. (2002). Prosedur Penelitian Suatu Pendekatan Praktik Edisi revisi $V$. Jakarta : Rineke Cipta.

Damin, S. (1995). Media Komunikasi Pendidikan. Jakarta : Bumi Aksara.

Darmanto. (1993). Media Visual. Bandung : Tarsito.

Hamalik,O.(1994). Media Pendidikan (Cetakan Ke 7). Bandung : PT Citra Aditya Bakti.

Hassoubah, I Z. (2004). Developing Creatif and Critical Thinking Skill (Cara Berpikir Kreatif dan Kritis). Bandung : Nuansa. 
Ibrahim, H., Sihkabuden, Suprijanta, \& Kustiawan, U. (2001). Media pembelajaran: Bahan sajian program pendidikan akta mengajar. FIP. UM.

Kusrianto, A. (2006). Panduan Lengkap Memakai Macromedia Flash 8. Jakarta : PT Elek Media Kompotindo.

Mulyasa. (2006). Kurikulum Tingkat Satuan Pendidikan. Bandung : PT Rosdakarya.

Poerwodarminto, W. J. S. (2002). Kamus Umum Bahasa Indonesia. Jakarta: Rineka Cipta.

Rachmanto, N B. (2005). Using Training Aids In Training And DedevelopmentA Practical Guide For Trainers And Presenters Leslie Rae"Memaksimalkan Potensi Alat Bantu Dalam Pelatihan dan Pengembangan. Jakata : PT Bhuana Ilmu Populer.

Sadiman, Arif S. (2009). Media Pendidikan. Jakarta : PT Rajagrafindo Persada.

Setiadi. (2007). Anatomi dan Fisiologi Manusia. Yogyakarta : Graha Ilmu.

Slameto. (2003). Belajar dan Faktor-faktor yang Mempengaruhinya. Jakarta: Rineka Cipta.

Winkel, W.S. (2007). Psikologi Pengajaran. Yogyakarta : Media Abadi. 